\title{
Principles of constructing, calculation methods of direct current hybrid contactors for alternative \\ energy
}

\author{
A. G. Soskov \\ Department of alternative energy and electrical engi- \\ neering \\ O.M.Beketov National University of Urban Economy \\ in Kharkiv \\ Ukraine
}

\author{
Ya. B. Forkun \\ Department of alternative energy and electrical engi- \\ neering \\ O.M.Beketov National University of Urban Economy \\ in Kharkiv \\ Ukraine
}

\author{
S. V. Kotelevets \\ Department of alternative energy and electrical engineering \\ O.M.Beketov National University of Urban Economy in Kharkiv
}

Ukraine

\begin{abstract}
It is shown that the principle of control and voltage supply of the hybrid DC contactor network is realized by connecting the electronic circuit with one terminal between two counter-actuated power-operated semiconductor devices of the two-way key, which shunts the main contacts of the first pole of the contactor, and the second terminal Luce. As a result, the network voltage is fed to the electronic circuit only for a short period of time (several ms), which is determined by the value of the time flow of the load current through the shunted bidirectional NC under the disconnected load.
\end{abstract}

The features of the process of current flowing from the main contacts to the circuits of switching on and off power controlled devices and the charge of the switching capacitor are determined. It was found that in order to ensure reliable switching in the entire range of switching currents of the contactor, it is necessary that the parameters of the elements of the switching circuit and the charge circuit of the switching capacitor were selected on the condition that the current in the switching circuit of the power $\mathrm{NC}$ at the moment of its switching was equal to the current in the charge circuit of the switching capacitor. In this case, the value of this current should not be less than the maximum switching-off current of a fully controlled NC. This makes it possible to reasonably approach the determination of the parameters of the elements, which ensure the secure locking of the two-directional NC.

As a result of the studies, it was also shown that the proposed hybrid contactors due to the introduction of voltage control of the network compared to the existing ones have competitiveness enhancing properties. In particular, they increase the reliability of the work, they do not need to supply an additional source of power, they exclude standard drivers, minimize energy consumption. Thus, an exemplary aspect of using the scientific result obtained is the ability to create competitive on-line hybrid DC contactors with a voltage up to $1000 \mathrm{~V}$ and currents of $100 \div 600 \mathrm{~A}$ for alternative energy.
Key word- hybrid contactor, main contact elements, two directional semiconductor key, voltage control

\section{INTRODUCTION}

In global industrialized countries is emerging a trend to widespread development both microgrids of direct current and low voltage (up to $1000 \mathrm{~V}$ ), and high voltage distribution system of medium voltage (up to $10 \mathrm{kV}$ and higher) [1]. The above-said is caused by the intensive development of so called «Smart Grids», that widely use alternative sources of energy, as a rule, wind turbine generators and solar electric plants.

For all such essential advantages of direct current micro grids, as low losses of power, lack of reactive power, they have own problems connected with a lack of serviceable switching devices, that is caused by the complexity of practical implementation of arch control conditions in direct current grids[2]. Nowadays in the most successful ways are allowed to solve this very above-mentioned problem the hybrid switching devices, that combine with the advantages of contactless devices (archless commutation) and contact ones (low losses of power in conducting state), two directional current of energy[3].

In connection with this the works directed at the invention of new construction principles of more effective hybrid commutation devices, including contactors, and also at the development and improvement their calculation methods are no doubt, actual ones..

\section{LITERARY REVIEW AND PROBLEM TA PROBLEM SETTING}

The conducted analysis of informational sources of the last years has revealed, that the invention of technical solution on producing and modernization of direct current hybrid commutation devices is under the way in the whole world in two directions: producing of circuit breaker assemblies (quick-breaking automatic switches) and produc- 
ing control devices (contactors, starters, relays) for low (up to $1 \mathrm{kV}$ ) and medium (up to $10 \mathrm{kV}$ ) voltage

So in the works $[1,2,4]$ considered hybrid switches, capable to interrupt emergency current within several milliseconds. They are started implementing as in direct current low voltage microgrids, as in high voltage direct current systems (HVDC). The principles of their construction are indicated, the effectiveness of their workis proved by the modelling results. Herewith the main problem, that is difficult to implement, is the invention of the drive of quickbreaking mechanical key.

In the work [5] is indicated, that semiconductor keys (SK for the direct current switches, were made on the background of carbide and silicone CiT-transistors type SiC-BGSiTs (silicon carbide baried gate static induction transistors) are vastly superior according to their electrical qualities to the keys, that are installed in other semiconductor devices.

In all above-mentioned hybrid switches are used as the basic ones expensive and complicated quick-breaking mechanical keys, and for the semiconductor keys control, that derive them, are used expensive and large format standard drivers with the power from additional voltage sources. Along with the clear benefits it creates some problems for the implementation of such technical solutions on invention of more simpler devices, such as contactors, whereabout the price and size format have the primary value.

Lower are given the review of sources, where considered the technical solutions, that belong to the second one of the above-mentioned approaches.

In [6] is offered the direct current hybrid electromagnetic contactor, parallel to the main contacts is connected two directional contactless switches, that are made in the form of a separate block. The control pattern synchronization work is carried out through the additional contacts, that kinematically connected with the main contacts. Its disadvantages: is not available grid galvanic isolation and load, for its power is used additional source of energy, the electrical part of pattern is under the load, as in in conducting state, and in off mode state of the contactor, it can't be used in the reverse pattern of power.

In [7] is given the high voltage direct current contactor, archless commutation of which is provided by two directional contactless switch, that through the additional power contact connected paralleled to the main contact. At that the additional contact switches on earlier the main contact during the switching-on and switches off later, than the main contact during the switching-off of the contactor. On the contrary the earlier contactor provides galvanic isolation of the grid and the load. Their disadvantages are: the availability of rather expensive and complicated control scheme, is not demonstrated, how is carried out, the energy dispersing, that is saved in the induction of the grid and the load, it could be used in the reverse patterns of power.

In the work [8] is researched the direct current hybrid contactor for the voltage $2 \mathrm{kV}$, made on the basis of vacume switch. The carried out researches proved its reliable work. Its disadvantages: it is not designed for work in the reverse patterns of switching-on, needs additional source of energy of high power and has high cost.
In the $[9,10]$ are researched the ways of perspective development of high resourse hybrid devices of direct current of new generation, designed for operative commutation of electrical energy in autonomous systems of power supply. The considered physical phenomena, that explain the commutation laws in direct current circles. The disadvantages of high resourse commutation hybrid devices of direct current: complicated kinematical ties in the structure of such devices and the very fact, that the maximal value of the current, that is safely commutated, does not exceed 100 A.

In [3] the researched row of hybrid contactors of direct current with better characteristics, proposes the calculation methods of its major units. Unfortunately, the presented samples do not support the two directional current flow in its circuit and that is why can't be used in the grids with the usage of alternative sources of energy.

The conducted literary review demonstrates, that the researches and development of direct current hybrid commutation devices is going on in the world rather effectively.

The conducted analysis of direct current hybrid contactors samples demonstrated, that along with the peculiar to them positive qualities, they have disadvantages, that reduce their competitiveness, in the market of electrotechnical production. That is why in demand are the researches, directed to the invention of new improved samples of hybrid contactors, where not only are removing lacks, but also creating new qualities, that rise their competitiveness.

\section{AIM AND GOALS OF THE RESEARCH}

The aim of research is inventing new principles and calculation methods of modes and parameters of direct current hybrid contactors for the alternative energy systems. lems:

For achieving the aim in the we should solve such prob-

to perform theoretical and experimental researches of non stationary electromagnetic processes, that support control and power of electronic circuit of hybrid contactor from the grid voltage;

to work out the methodology of parameters elements calculations of electronic circuit of hybrid contactor from thr grid voltage and give the recommendation on the famous calculation methodologies usage;

\section{TECHICAL SOLUTIONS ON INVENTING DIRECT CURRENT HYBRID CONTACTORS FOR THE SYSTEM OF ALTERNATIVE ENERGY AND THEIR ANALYSIS}

In O.M.Beketov National University of Urban Economy in Kharkiv (Ukraine) the technical solutions had been worked out, that are given in the form of two variants of electrical circuits two directional hybrid contactors with control and power of electronic circuit from the voltage grid. This principle and its implementation is protected by

The electrical circuit of the first variant of contactor is used as two directional semiconductor key of two back-toback IGBT- transistors is given in the figure 1 , a, and the second variant with the usage of two operational thyristors 
in the figure $1, \mathrm{~b}$. As the basic contact device is used the classical two-pole electromagnetical contactor.

In these circuit the elements: main contacts $\mathrm{MC} 1$ and MC2, current relay MR1, IGBT-transistors VT1,VT2 and backward diodes VD1,VD2, or two operational thyristors VS4, VS5 and the same diodes VD1,VD2 (two directional keys), make the main force field of the contactor. The openings MC1 and MC2 are regulated in such a way, that the second main contact is disconnected later than the first one (the round trip delay time is $5 \square 6$ milliseconds.). As the contacts MR1.1 and MR1.2 current relay are used magnetically operated switches (seal switches). Voltage-depended resistors R10 and diodes VD7, VD8 serve for energy dispersing, saved in the grid inductivity, and voltagedepended resistor VS3 and diode VD9 - for dispersing energy induction load in the moment of current interruption. At this time the usage of voltage-depended resistor instead of the diode allows to use the offered contactor in the reverse circuit of switching.

The charging resistor R9 and charging thyristor VS2 serve for the charging of commutation condensor для $\mathrm{C} 4$. Elements: diodes VD4, VD5, contact MR1.1, resistor R5, two directional transorb VD3, make the circuit of two directional key, and commutation condensor $\mathrm{C} 4$, commute thyristor VS1, entering circuit of option thyristor VS3 and restricting resistor R5 - the circuit of its switchinhg.

Resistor R7, contacts MR1.2, condensator C5 and the threshhold switch VD9 provide the timed delay for the switching off the charging thyrystor VS2.

At that the above/mentioned elements by means of their original switching on [11] are voltage carrying only for the short period of time $3 \square 4$ milliseconds, that counts from the moment of current flowing in the grid to the two directional key before the beginning of other main contacts. In the switched off and switched states of the contactor all the elements of its electronic parts are deenergized.

The detailed description of the contactor work and its peculiarities are given in [11].

As follows from the above/said. the proposed by the author technical solutions on control and power of electronic part of the contactor from the grid voltage allow to invent direct current hybrid contactors for the system of alternative energy, that in comparison to the existing systems of alternative energy allow to invent the direct current hybrid contactors for the systems of alternative energy, that in comparison to the existing ones have such supplementary positive qualities

- provide reliable archless commutation of the two directional current in the grid as during its both during its switching on, and during its switching off;

- suitable for the usage in the reverse switches on circuits;

- do not need additional source of power;
- they have economic work mode of the electronic parts components. Because they are only in the commutation moment of controlled two directional key are voltage carrying, it means that only during several milliseconds, and for a long time of the state on and state off of the contactor are practically in the saving mode that sufficiently raises the contactor work reliability (its is well known, that intensity of electronic components failure, that are not voltage carrying, is in several times less, than in voltage carrying elements);

the voltage in the commute condenser in the commutation process does not depend on neither the grid voltage, nor the circuit current, and is determined only by the value of Zener diode voltage, that switches on commuting thyristor, that essentially widens the opportunities of electronic circuit unification;

- - there is no need to use for the commutation the two directional semiconductor key, high cost and big format drivers with the special source of power.

The mentioned above raises substantially the competitiveness of the proposed contactors through the improving of functional qualities and production simplicity.

In the cases of these contactors usage in the circuits with one direction current is proposed to use the simplified variant, where are not available transistor VT2 ( picture 1, a) or thyristor VS2 ( picture 1,b) and diodes VD2, VD7 (picture 1, a; picture 1,b). At that the circuits of these elements are short together, and completely removed diodes VD5, VD8, VD9 (picture 1,a; picture1,b).

For the grounding of the received in this chapter results, and also for supporting of practical implementation is necessary to conduct theoretical and experimental researches of processes, that are under the way under the contactors circuits load commutation, and also on the basis of the obtained at that common patterns prepare the necessary calculations methods or recommend the existing ones.

\section{THEORETICAL RESEARCHES OF NON STATIONARY PROCESSES IN THE CIRCUITS OF CONTACTOR ELECTRONIC PARTS}

The calculation scheme for the research of non stationar electrical processes in the control and power circuits is indicated in the figure 2 .

The assumed in this pattern switching on of the circuit power of the commute condensor ( $\mathrm{C} 1, \mathrm{R} 3$, VS4) and the circuits of time delay (R4, C2) between back-to-back IGBT-transistors (VT1, VT2) or back-to-back operational thyristors (VS1, VS2) (their switching on is marked by the hashed lines) brings to that, that the grid voltage to these circuits is applied only by flowing the current from the circuit of the main contacts MC1 i MC2 (fig.1) to two directional semiconductor key. Under the closed upper connections in the switching on state of the contactor and under their breaking in the switched off state, the grid voltage is not forwarded to these circuits. 


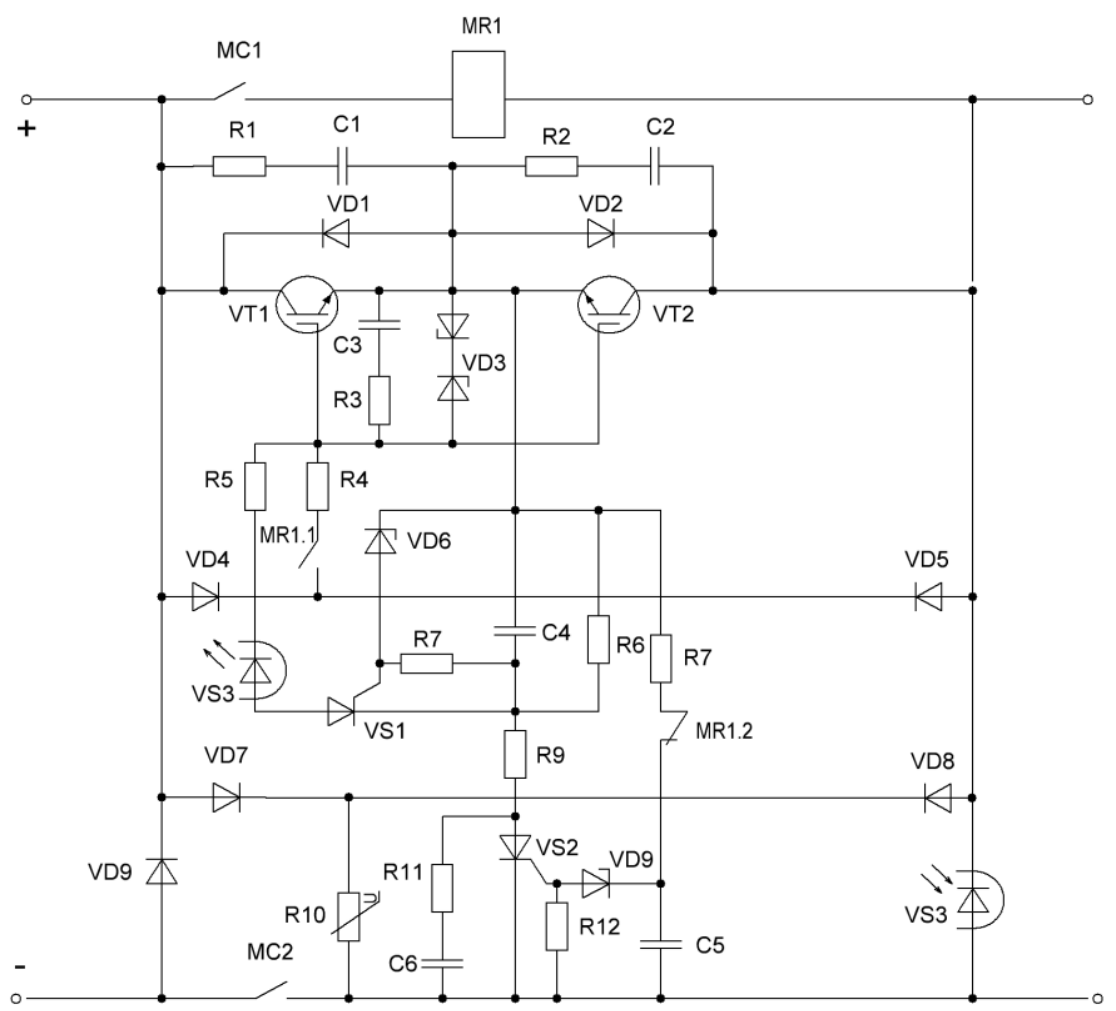

a)

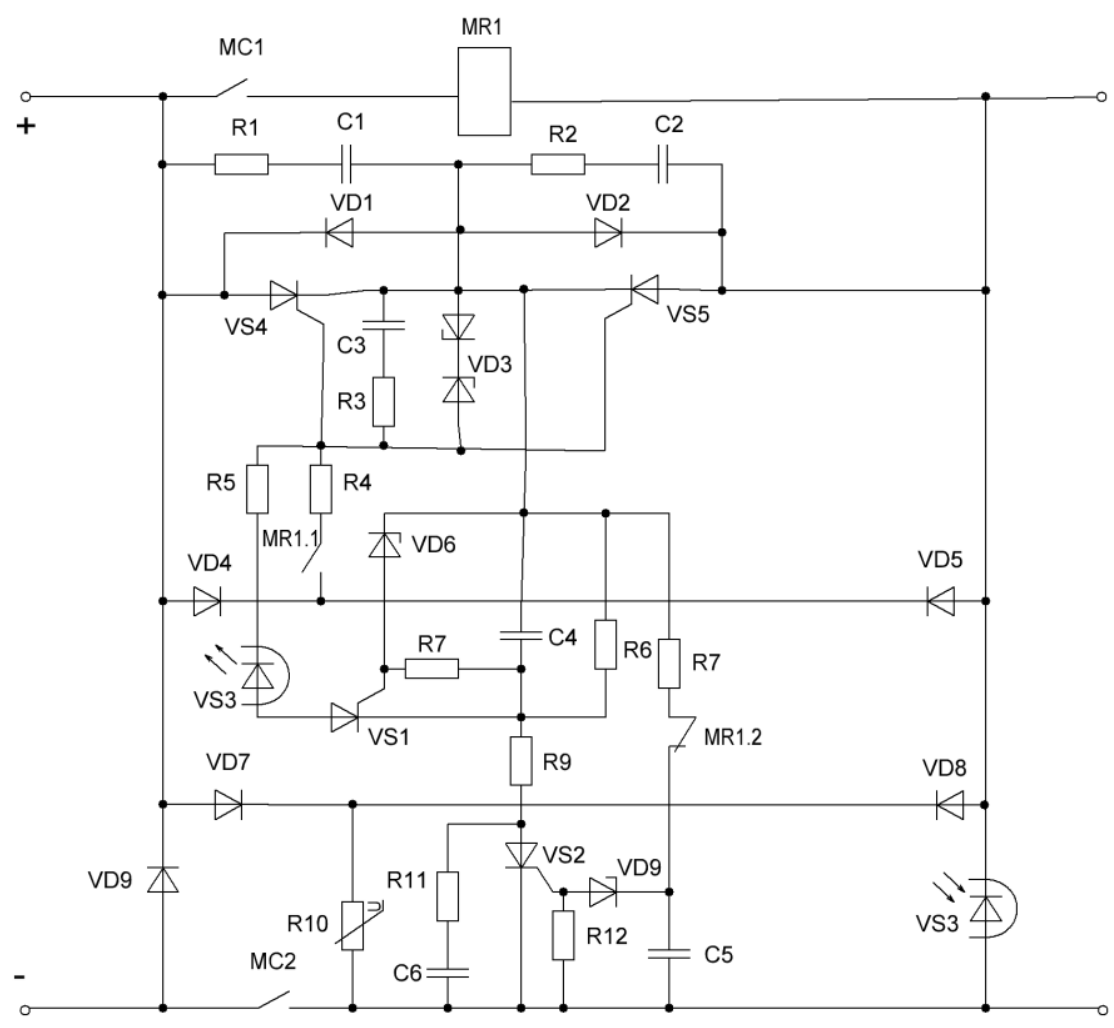

б)

Fig. 1. Electrical pattern of two variants of direct current hybrid contactors with the control and power from the voltage grid: a - on the basis of IGBT-transistor, $\sigma$ - on the basis of two operational thyristors 


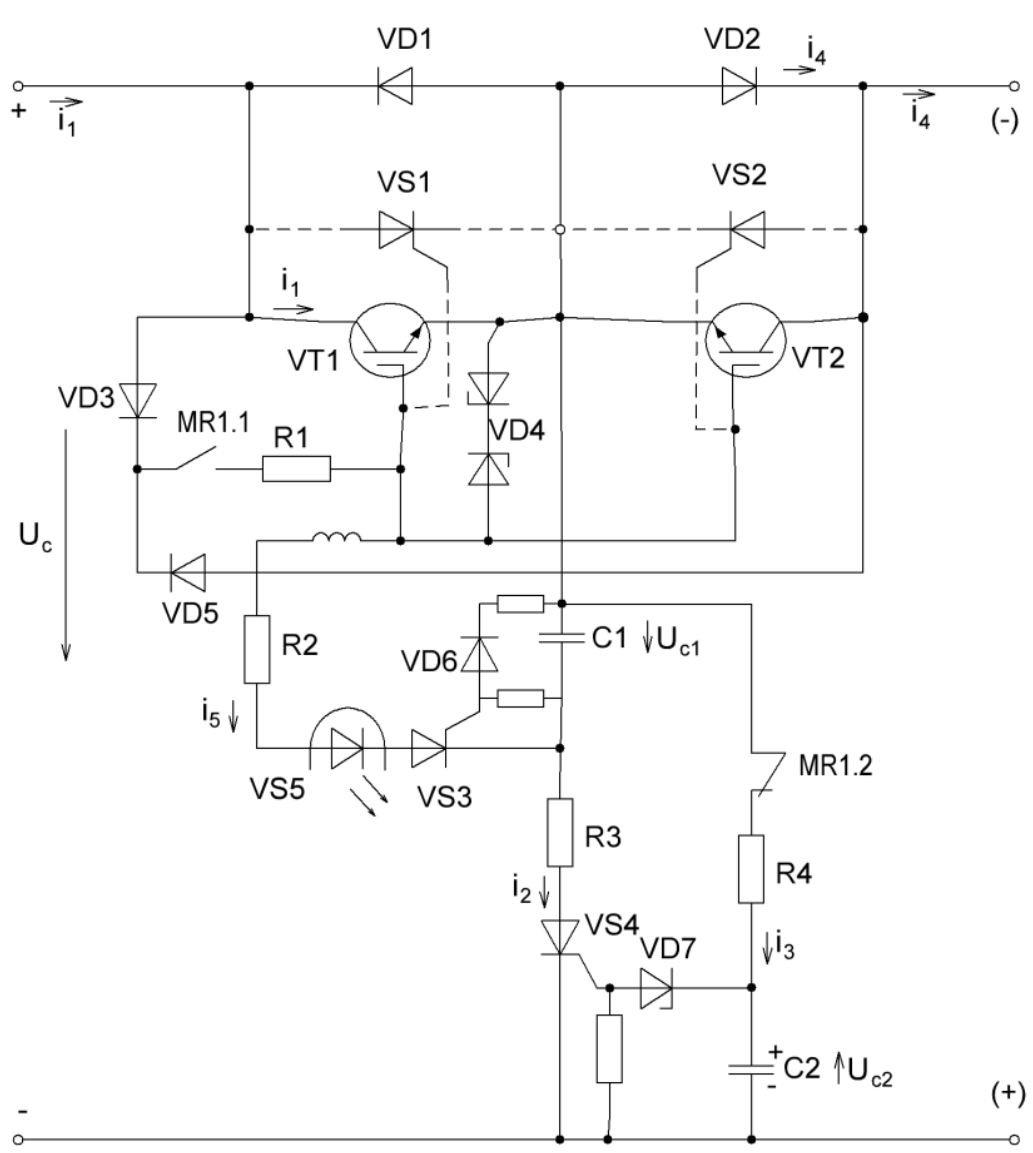

Fig. 2. Calculational pattern for research of electromagmetical processsses in control and power circuits.

Using the known calculation methods of transient phenomena [12], that are under the way in the indicated above circuits, we receive the following calculation ratios.

For the circuit of the commute condensor charge after switching of charging thyristor VS4:

$$
\begin{gathered}
U_{C_{1}}=U_{\mathrm{CT} 1}=\left(1-e^{-t / \tau_{1}}\right) \cdot U_{C} \\
U_{C_{1}}=U_{\mathrm{CT} 1}=\left(1-e^{-t / \tau_{1}}\right) \cdot U_{C} \\
t_{1}=\tau_{1} \cdot \ln \frac{U_{C}}{U_{C}-U_{\mathrm{CT} 1}}
\end{gathered}
$$

where Uc - control voltage, $\tau_{1}=R_{3} \cdot C_{1}$;

UCT1 - Zener voltage voltage stabilitron tubeVD6, $U_{C T 1}$ -

$t_{1}$ - condenser charging time $\mathrm{C} 1$ up to the voltage

For the time delay after contacts breaking MR1.2:

$$
\begin{gathered}
i_{3}=\frac{U_{C}}{R_{4}} \cdot e^{-t / \tau_{2}} \\
U_{C_{2}}=U_{\mathrm{CT} 2}=\left(1-e^{-t / \tau_{2}}\right) \cdot U_{C} \\
t_{2}=\tau_{2} \cdot \ln \frac{U_{C}}{U_{C}-U_{\mathrm{CT} 2}}
\end{gathered}
$$

where $\tau_{2}=R_{4} \cdot C_{2}$

$U_{C T 1}$ - UCT1 - voltage of stabilitron tube stabilization VD7,

t2 - condenser charging time $\mathrm{C} 2$ up to stabilization voltage VD7.

$$
\text { At that } \begin{array}{r}
i_{1}=i_{2}+i_{3}+i_{4}, \\
t_{3 \mathrm{aT}}=t_{1}+t_{2},
\end{array}
$$

where $i_{4}--$ current load,

$t_{3 a \mathrm{~T}}-$ switching off delay time in the circuit of two directional semiconductor key. 
A. G. Soskov, Ya. B. Forkun, S. V. Kotelevets, Вип.54, №01.

If reached the voltage value in the commute condenser of $\mathrm{C} 1$ level by the stabilitron tube test VD6 the commute thyristor VS3 is switching on and the condenser voltage C1UC1 is applied in inverse direction, before the ingoing of two directional semiconductor key.

For that to prevent the voltage rising to $\mathrm{C} 1$ after switching-on VS4 is necessary, that the currents il and i5 within this period of time were the same. Under this value of the current i5 is determined for the variant using IGBT- transistor from the formula

$$
i_{5}=i_{2}=\frac{U_{C T 1}-U_{V D 4}}{R_{2}} \geq I_{\kappa V S 5},
$$

where UVD4 - the voltage test of two directional clipper VD4;

IKvs5 - the current of ingoing circuit of option tube thyristor VS5, that provides its reliable switching-on.

For the variant using two operational thyristor of the current value i5:

$$
i_{5}=i_{2}=\frac{U_{\mathrm{CT} 1}}{R_{2}} \geq I_{G Q}=\frac{I_{\mathrm{HM}}}{K_{\Pi}},
$$

where $\mathrm{I}_{\mathrm{GQ}}$ - value of reverse gate current, that provides the reliable switching off of maximal reliable commutation current $\mathrm{I}_{\mathrm{HM}}$;

amplification factor $=3 \div 4$ - amplification factor during the switching off of two operational thyristor.

At that, because the value of the reverse gate current transformation of closed looped thyristor VS2 under reverse voltage usually does not exceed $10 \div 20$ мA $[13,14]$, because its influence on the process of switching off VS1 may neglect. The is belong to the case with the usage of IGBT-transistors.

For the value choice of commuting condenser volume we analize the following processes in the variant case using the IGBT- transistors and the variants using two operational thyristors

In the case using IGBT-transistors after switching-on commuting thyristor після VS3 IGBT-transistor VT1 is locked over center practically momentary(quicker than 1 microsecond). As a result, the grid voltage switches off from the charger department, and beforehand charged condenser $\mathrm{C} 1$ starts discharging through the resistor R2 in input VT1. At that the charging current is determined according to the formula

$$
i_{\mathrm{po3} 1}=\frac{U_{\mathrm{CT} 1}-U_{\mathrm{VD} 4}}{R_{2}} \cdot e^{-t / \tau_{\mathrm{p} 031}},
$$

where $\tau_{\text {роз } 1}=R_{2} \cdot C_{1}$.

For that, that the optical isolator thyristor VS5 could reliable switch on, is necessary, that

$$
i_{\text {роз1 }}\left(t_{\text {вкл }}\right)=\frac{U_{\mathrm{CT} 1}-U_{\mathrm{VD} 4}}{R_{2}} \cdot e^{-t_{\text {вкл }} / \tau_{\text {ро32 }}} \geq I_{\text {вкл }},
$$

where $I_{\text {вкл }}$ and $t_{\text {вкл }}$ - current and time of switching of optical isolator thyristor VS5.

After the corresponding transformations of these formulae we receive the following formula for the commuting condensor

$$
C_{1}=\frac{t_{\text {вкл }}}{R_{2}} \cdot \ln \frac{U_{\mathrm{CT} 1}-U_{\mathrm{VD} 4}}{R_{2} \cdot I_{\text {вкл }}},
$$

where $\frac{U_{\mathrm{CT} 1}-U_{\mathrm{VD} 4}}{R_{2} \cdot I_{\text {вкл }}}=e$, according to the conditions of maximal energy usage of condensor charge.

In the variant case of using two operational thyristors during the choice of elements parameters of the switching of scheme of two operational thyristor is worth mentioning, that the thyristor breaking time is located within the range from 70 to 100 microseconds [13], and gate turn-off current - within the limits from dozens to hundreds amperes depending on the value of the breaking by the contactor current.

In this variant after switching-on of commuting thyristor VS3 through the controlling transformation of the thyristor VS1 starts flowing current, which value doesn't determined according to the formula (10), which speed of growing will not exceed the admitted value owing to the availability of own contour commutation induction [13]. As so as we have a full filled stipulation, the voltage in the commuting condensor is equal. After the period of time, that equals is the decline of current under the wayв, commuting by VS, up to of $10 \%$ of its initial value[13]. At that also stridently growing the resistance of controlling transformation VS1 and voltage decline in it, and availibility of protective two directional voltage selector VD4 prevents from the possible breakdown the controlling transformation VS1. And only in this moment of time starts discharging the commuting condensor.

$$
u_{C}=U_{\mathrm{CT} 1} \cdot e^{-t / \tau_{\text {ро3 }}}
$$

where $\tau_{\text {роз } 1}=R_{2} \cdot C_{1}$,

$R_{\text {екв }}$ - equivalent resistense, which value is being defined by the experimental control with the particular type of chosen two operational thyristor.

By (14) the way of corresponding transformation[12] we receive:

$$
C_{1}=\frac{t_{\text {off }}-t_{G Q}}{R_{\text {екв }}} \cdot \ln \frac{U_{\mathrm{CT} 1}}{U_{\text {Со }}}
$$

where $U_{\mathrm{CT} 1}$ - discharge voltage in the condensor after finishing the switching off in the condensor VS1, as a rule $U_{\mathrm{Co}}=0,1 \cdot U_{\mathrm{CT} 1}$, then $\ln \frac{U_{\mathrm{CT} 1}}{U_{\mathrm{Co}}}=2,3$.

For the condenser $\mathrm{C} 2$ we use the formula (6). After the corresponding transformation we have: 


$$
C_{2}=\frac{t_{2}}{R_{4}} \cdot \ln \frac{U_{\mathrm{C}}}{U_{\mathrm{C}}-U_{\mathrm{Co}}},
$$

where $I_{\mathrm{KVS} 4}-$ gate current that provides reliable switching-on VS4,

$$
\begin{gathered}
t_{2}=t_{\text {зад }}-t_{1}, \\
R_{4}=\frac{U_{\mathrm{C}}-U_{\mathrm{CT} 2}}{I_{\text {кVS4 }}}, \\
t_{1}=R_{3} \cdot C_{1} \cdot \ln \frac{U_{\mathrm{C}}}{U_{\mathrm{C}}-U_{\mathrm{CT} 1}}, \\
R_{3}=\frac{U_{\mathrm{C}}-U_{\mathrm{CT} 1}}{I_{G Q}}, I_{G Q}=\frac{I_{\mathrm{HM}}}{K_{\Pi}} .
\end{gathered}
$$

VI. CALCULATION RESULTS OF ELEMENTS PARAMETERS IN THE CONTROL NETWORK AND POWER IN ELECTRONIC PART OF CONTACTOR

In the tables 1 and 2 are presented the calculative values of the basic parameters of power and control network during the commutation of maximal current of contactor for the pattern variants given under the maximal contactor current presented in the fig. 2 .

The calculations were made according to the formulae $(1) \div(16)$.

The outgoing data for the calculation were the following parameters:

- Maximal commutational current ( - nominal current);

- grid voltage;

- switching on delay time milliseconds;

- voltage $\mathrm{V}$,

- input voltage limit value VT1 or VS1 $\pm 15 \mathrm{~V}$,

- two operational thyristor amplification centre,

- breaking time IGBT-transistor ufd,

- breaking time of two operational thyrister microsec-

\begin{tabular}{|c|c|c|c|c|c|c|c|c|c|c|c|}
\hline \multirow[b]{2}{*}{$\boldsymbol{I}_{\text {ном, }}, \mathrm{A}$} & \multirow[b]{2}{*}{$U_{\text {ном, }}$, В } & \multicolumn{6}{|c|}{ Power circuit parameters } & \multicolumn{4}{|c|}{ Parameters of switching circuits } \\
\hline & & $C_{2}$, ufd & $\begin{array}{c}I_{K V S 3}, \\
\quad A\end{array}$ & $\mathrm{R}_{3}, \mathrm{Ohm}$ & $\mathrm{R}_{4}, \mathrm{Ohm}$ & $\begin{array}{c}t_{1}, \\
\text { mi- } \\
\text { cro } \\
\text { sec } \\
\text { ond } \\
s\end{array}$ & $t_{2}, \mu c$ & $I_{K V S S,} A$ & $C_{1}, \boldsymbol{м к \phi}$ & $R_{2}, O_{M}$ & $I_{\text {pos } 1, ~} A$ \\
\hline 100 & \multirow{5}{*}{600} & 20,0 & 0,1 & $2,14 \cdot 10^{3}$ & $5,8 \cdot 10^{3}$ & 24 & \multirow{5}{*}{4,0} & 0,1 & 0,33 & 18,4 & 0,271 \\
\hline 160 & & 20,0 & 0,1 & $2,14 \cdot 10^{3}$ & $5,8 \cdot 10^{3}$ & 24 & & 0,1 & 0,33 & 18,4 & 0,271 \\
\hline 250 & & 20,0 & 0,1 & $1,07 \cdot 10^{3}$ & $5,8 \cdot 10^{3}$ & 24 & & 0,2 & 0,66 & 9,2 & 0,542 \\
\hline 400 & & 40,0 & 0,2 & $1,07 \cdot 10^{3}$ & $2,9 \cdot 10^{3}$ & 24 & & 0,2 & 0,66 & 9,2 & 0,542 \\
\hline 630 & & 40,0 & 0,2 & $0,712 \cdot 10^{3}$ & $2,9 \cdot 10^{3}$ & 24 & & 0,3 & 1,0 & 6,13 & 0,815 \\
\hline
\end{tabular}
onds,

- current growing speed of thyristor block out $200 \div 80$

\begin{tabular}{|c|c|c|c|c|c|c|c|c|c|c|c|}
\hline \multirow[b]{2}{*}{$I_{\text {nom. }}, \mathrm{A}$} & \multirow[b]{2}{*}{$U_{\text {nom }}$, B } & \multicolumn{6}{|c|}{ Power circuit parameters } & \multicolumn{4}{|c|}{ Parameters of switching off circuits } \\
\hline & & $C_{2}, u f d$ & $\begin{array}{c}\boldsymbol{I}_{K V S S 3}, \\
\boldsymbol{A}\end{array}$ & $\mathrm{R}_{3}, \mathrm{Ohm}$ & $\begin{array}{l}R_{4} \\
\mathrm{Ohm}\end{array}$ & $\begin{array}{c}t_{1}, \\
\text { mi- } \\
\text { cro- } \\
\text { sec- } \\
\text { onds }\end{array}$ & $t_{2,}, M c$ & $I_{G Q}, A$ & $C_{1}$, ufd & $\mathrm{R}_{2}, \mathrm{Ohm}$ & $\begin{array}{l}R_{\text {equ }} \\
\text { Ohm }\end{array}$ \\
\hline 100 & \multirow{5}{*}{600} & 20,0 & 8,1 & $5,8 \cdot 10^{3}$ & 4,66 & 8,1 & \multirow{5}{*}{4,0} & 72 & 17,0 & 0,277 & 2,0 \\
\hline 160 & & 20,0 & 5,0 & $5,8 \cdot 10^{3}$ & 3,39 & 5,0 & & 115 & 20,0 & 0,174 & 2,0 \\
\hline 250 & & 20,0 & 3,22 & $5,8 \cdot 10^{3}$ & 2,62 & 3,22 & & 180 & 24,0 & 0,41 & 1,5 \\
\hline 400 & & 40,0 & 2,04 & $2,9 \cdot 10^{3}$ & 2,46 & 2,04 & & 285 & 35,0 & 0,07 & 1,0 \\
\hline 630 & & 40,0 & 1,29 & $2,9 \cdot 10^{3}$ & 2,184 & 1,29 & & 450 & 50,0 & 0,0444 & 0,7 \\
\hline
\end{tabular}
$\mathrm{A} /$ milliseconds.

TABLE ICALCULATION RESULTS FOR PATTERN FIG. 2 ON THE BASIS OF IGBT-TRANSISTORS AT $I_{M}=2,5 \cdot I_{\text {ном }}$

TABLE II. CALCULATION RESULTS FOR PATTERN FIG.2 ON THE BASIS OF TWO OPERATIONAL THYRISTORS AT $I_{M}=2,5 \cdot I_{\text {ном }}$

It is obvious, that the elements calculation parameters were obtained from the commutation conditions of maximal admissible current that calculation parameters of electronic scheme elements were obtained from commutation conditions of maximal admitted current, provide the reliable commutation under more lower currents, moreover by wide margins. That is why we need not performing additional calculations. 
A. G. Soskov, Ya. B. Forkun, S. V. Kotelevets, Вип.54, №01.

The result analisis of the calculation proved, that the the principle of control and power supply of electronic scheme contactor from the voltage grid guarantees the following positive qualities:

- reliability of blocking totally controlled two directional semiconductor key in the full range of commuting current of the contactor, without using special high cost drivers and their power units;

- the electronic pattern elements are at load for the short time (not more than several milliseconds) only in the moment of breaking the grid;

- the breaking process of two directional semiconductor key is completely provided by the energy of power gridпроцес, that substantially (larger and more) lowers the mass and the cost of commuting contactor in comparison to the known variants of contactors[3, 16];

- the breaking circuit of two directional key in IGBTtransistors according to their large-format, cost, dispersing power substantially than key of circuit breakit in the two operational thyristor.

But in the zone of commuting currents according to overloading capacity of IGBT-transistors practically in three times are inferior to two operational thyristors[13]. The last results in, that by the similar nominal currents of the contactor the current of continuous rating ofIGBTtransistor approximately in several times will exceed the same current in the variant with the two operational thyristor.

In the result of the nominal currents higher than $160 \mathrm{~A}$ the usage the IGBT-transistor as the contactor of semiconductor key becomes economically unjustified, and usage as a semiconductor key two operational thyristor on the contrary, economically feasible, because of the large format and the cost the breaking circuit of operational thyristor is non-comparable less than the rest of the elements, this disadvantage will not be decisive when making a selection of two operational thyristor as a semiconductor key.

The calculation methodology of overloading capacity of totally controlled SS and also a varistor overload stop are indicated in $[3,15]$. it can be seen, that high-power semiconductor devices, that serve as SS in hybrid contactors are used without cooling agents. At that the value of maximal impulse current of the IGBT-transistor IGM and maximal current of two operational thyristor ITGOM should be not less than the value of the contactor maximal current, that is breaking.

The acceptable level of overload is less than is attained gradually and parallelly by means of switching on low power varistors with accepted mass and cost[15].

\section{EXPERIMENTAL RESEARCH OF THE LOAD COMMUTATIONAL PROCESS}

In this experiment is being surveyd the contactor maximal current commutation. At that the electronic pattern of the contactor within the range $I_{\text {ном }}=100 \mathrm{~A}$, $U_{\text {ном }}=100 \mathrm{~V}$.

The research was carried out in the special device, which electrical circuit is given in the fig. 3. In this pattern for the substantial lowering of the fed from the grid energy, and also for the breaking of the grid inductivityand also for the breaking of the grid inductivity effect on the commutational process, as a source of power is used earlier of the charging up to the voltage of $100 \mathrm{~V}$ the capacitor bank $C_{\varkappa}$ of great volume ( $\left.C_{\varkappa}=0,1 \mathrm{~F}\right)$, and as a load - the active resistance $R_{H}=0,4$ Ohm,

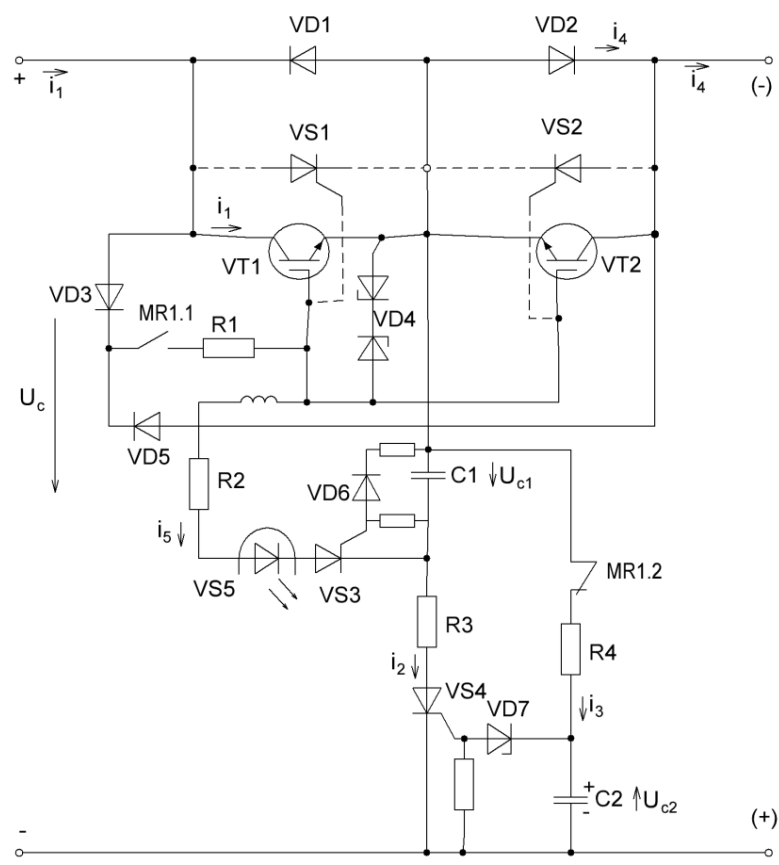

Fig. 3. Electrical pattern of the research device. 
The electronic pattern parameters are calculated according to the proposed above methodologies using such source: B, A, , B, B, B. The value of parameters of basic elements are indicated in the electrical pattern (fig. 3).

The circuit commutation is carried out with the help of the transistor, made on the base of IGBT-transistor of the firm ABB type 5SMY 12H/280.

The control circuit provides synchronical switching-on of the transistor and low power thyristor by the way of the voltage supplied for their input entrance short-time pulses $\mathrm{V}$ with a running time milliseconds. The mentioned above is going on by the way of pressing button «Start».

The measurement takes place with the help of digital oscilloscope and digital voltmeter. In the fig. 4 is given the typical oscilloscope of the current commutational process $\mathrm{A}$, where presented the load current and load voltage.

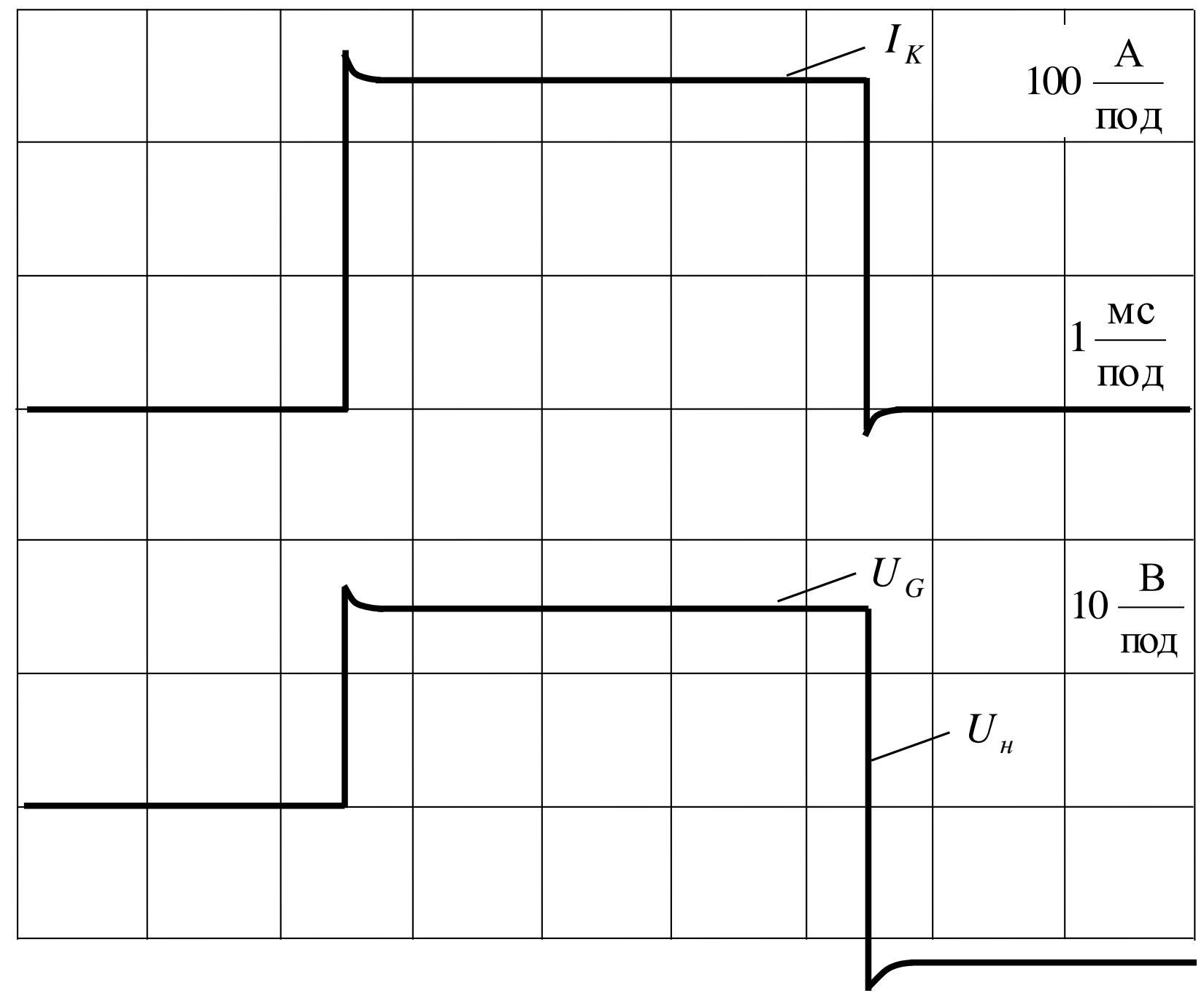

Fig. 4. Oscillograph chart of the load and voltage current in the gate og IGBT-transistor in the process of circuit breakage.

The measured by means of oscilloscope values of maximal current via thyristor and the voltage in commuting condensers in the commutation process do not differ from the calculation values by more than $7 \div 8 \%$.

In such a way, the results of the research proved the functionality of electronic pattern at the time of the load breaking.

\section{DISCUSSION THE RESULTS OF CARRIED OUT RESEARCH}

The usage of hybrid contactors of power and control of electronical scheme of the grid voltage allowed to obtain a number of positive qualities, that raise their competetiveness in the systems of direct current electricity transmission. It is achieved by, that an output of commutational condenser is connected between two back-to-back high power semiconductor devices of two directional key, and the second one - via charging resistor and thyristor to the output clamping unit of another contactor pole. Moreover, 
the indicated commuting condenser is connected via threshold switch to the input of commuting thyristor. In the circuit charge (time setting circuit) time plication delay condenser element is cut in supplementary normally contact of current relay, and the indicated condenser via the second threshhold switch, connected to the input of charging thyristor. As a result, the grid current supplied to the electronic pattern only for the short period of time (several milliseconds), that is determined by the time of current load flow via two directional semiconductor key, that shunts the first main contact.

In such a way is guarranteed the spare working regime of the pattern sparing regime of the pattern electronic components, they are practically in saving regime, that is the intensity of their breakdown is in several times less, than in their case of operation under load[14]. As a result reliability and life span of contactor is rising substantially, there is no longer any necessity for additional sources of supply and standard drivers, that are usually used in the existing samples. For the switching-on of totally controlled semiconductor devices is used the grid's electrical energy, but not of the commuting condenser, that radically reduces its mass and cost. The above mentioned radically simplifies the contactor's electrical circuit, and also lowers its cost in providing reliable archless commutatation load in two directional flow of the current in the circuit.

As a result are improving the functional qualities of the proposed contactors and is symplifying their industry engineereing, I.e. is increasing their competiveness.

The lack of the proposed cotactar is the influence in the process of grid load commutation process on some circuit elements, for example on charging thyristor and resistor and others, that complicates their usage at the grid voltage of more than $1000 \mathrm{~V}$ because of complication of producing electrical insulation of the mentioned elements, and because of the lack of low power semiconductor keys, capable to workat high voltage power.

As a result of conducted researches of non stationary processes, that take place in the contactor commutation circuit, were worked out operationable for engineering design calculation methods of the main components of electronic pattern of contactor. At that was shown, that for the parameters choice of the mentioned components, is sufficiently to make a calculation only in the case of maximal breakage of power by the contactor.

The scientific novelty of the carried out researches are that, as it has discovered, with a view to ensuring of reliable commutation throughout the operational range of commuting current of the contact is necessary, that the parameters elements of the run circuit and the charge circuit of the commuting condenser were chosen on conditions that, the current in circuit of commuting thyristor at the moment of its closing in was equal to the current in the circuit of charging thyristor. At that the value of the current should be not less than the maximal current of switching should not be less of the maximal current of totally controlled semiconductor device.

The results of caculations and experimental researches demonstrate the real capacity of direct current hybrid contactors for the systems of alternative electrical energy in- dustry, that are designed for the currents $100 \div 630 \mathrm{~A}$ and voltage up to $1000 \mathrm{~V}$.

Moreover, the obtained results of researches could be used in working out of hybrid contactors, that effectually to exploit in the frequent run-up of engines, for example in electrical transportation, in cranage crampon, in rolling of metallurgical plants etc., and also under conditions of recuperation of electrical energy into the grid.

\section{CONCLUSIONS}

1. It was grounded, that the proposed hybrid contactors in comparison with the existing ones have the following advantages:

- have the advanced work reliabilty thanks to introduction and technical solution, that provide power supply and control of the electronic pattern of the contactor from the voltage grid only for the short period of time (several milliseconds)while it is switching off. As a result their components, including two directional semiconductor key, for a long time, during switched on and switched off state of contactor is idly, i. e. practically in power saving mode, when intensivity of malfunctioning is next lower order, than under load condions;

- There is no need to use high priced abd large-format standard drivers and additional sources of power supply;

- in the result of usage of the proopsed technical solutions when constructing the ON circuits and shut-off circuits of two directional semiconductor key, and also a selection of rational operation of the mentioned circuit, was simlified the electrical pattern of contactor and lowered its costa.

2. It was specified that for the providing reliabble archless commutation within the full range of currents, that switches off the contactor, it is necessarly, that the parameters of the elements of breakage circuit and charge circuit of commuting condenser were chosen on the condition, that the current in the circuit of commuting thyristor at the moment of its switching on was equalled the current in the circuit of the charging thyristor. At that the value of the current should be not less, than the maximal breakage current of totally controlled semiconductor key. It was also demonsrated, that in this case for the breakage of controlled semiconductor devices is used the grid energy, but not a commuting condenser, that radically lowers its mass and cost.

3. The worked out calculations methods of the basic elements of electronic pattern of the contactor permit to carry out the above-mentioned calculations with the sufficient for engineering designs accuracy, that is proved by the results of experimental researches. At the volume of calculations is reducing, because it is necessarly to fulfil the under set above conditions, and only for the valuesof maximal commuting current for this completion of the contactor.

4. The results of calculations and experimenral researches demonstrate the real capacity of inventing competitive hybrid contactors of the direct current for the systems of alternative electrical energy industry for the currents from 100 to $630 \mathrm{~A}(100 \div 630)$ and voltage up to $1000 \mathrm{~V}$. 


\section{REFERENCES}

[1] Yang Gao, Xiaoguang Wei, Zhiyuan He, Longlong Chen, Yunhai Shan. A hybrid circuit breaker for DC-application. IEEE First International Conference. - 2015. - P. 187 - 192, doi: 10.110 /ICDCM.2015.7152036

[2] Y. Sato, Y. Tanaka, A. Fukui, , M. Yamasaki, O. Hiromichi.An investigation of SiC-SIT DC circuit breakers for higher voltage direct current distribution systems. Energy Conversion Congress and Exposition (ECCE), 2010 IEEE. - 2010. - P. 3290-3295, doi: 10.1109/ECCE.2010.5617760

[3] Сосков, А. Г. Гібридні контактори низької напруги покращеними техніко-економічними характеристиками [Текст] : монографія / А. Г. Сосков, Н. О. Сабалаєва ; Харк. нац. акад. міськ. госп-ва. - Х. : ХНАГХ, 2012. - 268 с.

[4] Hassanpoor, A.; Hafner, J.; Jacobson, B. Technical Assessment of Load Commutation Switch in Hybrid HVDCBreaker. Power Electronics, IEEE Transactions on Year: 2015, Volume: 30, Issue: 10 Pages: 5393 - 5400.

[5] Tanaka, Y. Development of semiconductor switches (SiC-BGSIT) applied for DC circuit breakers [Text] / Y. Tanaka; A. Takatsuka, T. Yatsuo, Y. Sato, H. Ohashi // Electric Power Equipment Switching Technology (ICEPE-ST), 2013 2nd International Conference. - 2013. P.1-4 DOI: 10.1109/ICEPE-ST.2013.6804323.

[6] Hybrid DC electromagnetic contactor: patent no. 7079363 B2 USA №10/404061 field: 2.04.2003 ; date of patent 18.07.2006

[7] Patent no. 7538990 B2USA, Int.Cl. H02H 3/00, H02H 7/00 High voltage contactor hybrid without a DC arc break[Text] /BelisleF.C., CarterE.A. MetzlerM.W., Wavering J.T. (USA). - 11/638984 ; field: 14.12.2006; date of patent 26.05.2009

[8] Lu Qi, Guogang Zhang, lingcun Liu, Zheng Qin, Yingsan Gend Jianhua Wang. Researching on integrated design of vacuum switch based on permanent magnetic actuator for DC contactor // Materials of 4th International Conferens of Electric Power Equipment- switching Technology (ICEPE). China, Xian, 2017, Oct. 22 - Oct. 25

[9] Ваткина М. А., Григорьев А. А. Перспективы развития низковольтных коммутационных гибри-дных аппаратов нового поколения на основе принципа гибридной коммутации // Вестник Чувашского государственного педагогического университета им. И. Я. Яковлева. 2013. №4 (80). Ч 2. С. 46-55.

[10] Ваткина М. А., Григорьев А. А. Оптимальный синтез физических явлений и процессов комму-тации низковольтных гибридных аппаратов // Вестник Чувашского государственного педа-гогического университета им. И. Я. Яковлева. 2014. №4 (84). C. 4-14.

[11] Пат. 130231 Гібридний двополюсний контактор постійного струму (Сосков А.Г., Сабалаєва Н.О., Форкун Я.Б., Глєбова М.Л.) заявка и 201806869 , дата подання заявки 18.06.2018, дата чинності патенту 26.11.2018, бюл. № 22.

[12] Зевеке Г. В., Ионкин П. А., Нетушил А. В., Страхов С. В Основы теории цепей: учеб. - 5 изд. перераб. и доп. Москва, $1990.528 \mathrm{c}$.

[13] Воронин П.А. Силовые полупроводниковые ключи: семейства, характеристики, применение. Изд. 2-е перераб. и доп. Москва, $2005.384 \mathrm{c}$.

[14] Уильямс Б. Силовая электроника: приборы, применение, управление: справочное пособие; пер. с англ. Н.Н. Ильин. Москва, 1993. 462 с.

[15] Soskov A. G., Sabalayeva N. O., Forkun Ya. B., Glebova M. L. Methods of overvoltage limitation in modern DC semiconductor switching apparatus and their calculation //Eastern-European Journal of Enterprise Technologies. 2016. Vol. 3/8 (81). P. 4-9.

[16] A. G. Soskov, N. O. Sabalayeva, Ya. B. Forkun, M. L. Glebova Development Of Principles And Methods Of Calculation Of Direct Current Hybrid Contactor // Eastern-European Journal of Enterprise Technologies. - 2018. - Vol. 2/5 (92). P. 48-63

\section{Принципи побудови, методи розрахунку гібридних контакторів постійного струму для альтернативної енергетики}

\author{
А. Г. Сосков \\ Кафедра альтернативної електроенергетики та елек- \\ тротехніки \\ Харківський національний університет міського гос- \\ подарства імені О.М. Бекетова \\ Україна
}

\author{
Я. Б. Форкун \\ Кафедра альтернативної електроенергетики та елек- \\ тротехніки \\ Харківський національний університет міського гос- \\ по-дарства імені О.М. Бекетова \\ Україна
}

\section{С. В. Котелевець \\ Кафедра альтернативної електроенергетики та електротехніки \\ Харківський національний університет міського господарства імені О.М. Бекетова \\ Україна}

Анотація - Показано, що принцип керування та живлення напругою мережі гібридного контактора постійного струму реалізовано шляхом підключення електронної схеми одним виводом між двома зустрічно включеними силовими керованими напівпровідниковими приладами двонапрямного ключа, який шунтує головні контакти першого полюса контактора, а другим - до вихідного затискача другого полюса. В результаті напруга мережі подається на електронну схему тільки на короткий проміжок часу (кілька мс), який визначається значенням часу протікання струму навантаження через шунтуючий двонапрямний НК за відключеного навантаження.

Визначені особливості процесу перетікання струму з кола головних контактів в кола включення та відключення силових керованих приладів та заряду комутуючого конденсатора. При цьому було встановлено, що для забезпечення надійної комутації в усьому діапазоні вимикаємих струмів контактора необхідно, щоб параметри елементів кола ввімкнення та кола заряду комутуючого конденсатора були обрані з умови, що струм в колі вимкнення силового НК в момент ії включення дорівнював струму в колі заряду комутуючого конденсатора. При цьому значення цього струму повинно за бути не меншим максимально-

DOI: $10.33042 / 2079-424 X-2019-1-54-18-29$ 
A. G. Soskov, Ya. B. Forkun, S. V. Kotelevets, Вип.54, №01.

го струму вимкнення повністю керованого НК. Це дозволяє обгрунтовано підходити до визначення параметрів елементів, що забезпечують надійне запирання двонапрямного НК.

В результаті проведених досліджень також було показано, що пропоновані гібридні контактори завдяки введенню керування напругою мережі у порівнянні з існуючими мають властивості, що підвищують конкурентоспроможність. Зокрема в них підвищена надійність роботи, вони не потрібують для живлення додатково-го джерела живлення, в них виключені стандартні драйвери, до мінімуму зведено споживання енергії. Таким чином, прикладним аспектом використання одержаного наукового результату є можливість створення конкурентоспроможних на-дійних гібридних контакторів постійного струму на напругу до

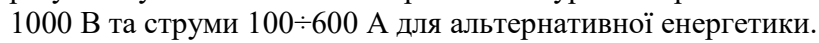

Ключові слова - гібридний контактор, основні контактні елементи, двонаправлений напівпровідниковий ключ, контроль напруги 